\title{
An alternate technique for isolation of Toxocara canis excretory- secretory antigens
}

\author{
Cristiane Maria Colli', Guita Rubinsky Elefant ${ }^{2}$, Marcia Liz Paludo³, \\ Ana Lúcia Falavigna Guilherme, ${ }^{1, *}$ \\ ${ }^{I}$ Department of Clinical Analysis, State University of Maringá, ${ }^{2}$ Institute of Tropical Medicine of São Paulo, \\ ${ }^{3}$ University of Paraná, Paranavai
}

\begin{abstract}
The aim of the present study was to test the effectiveness of a sausage-casing membrane for dialysis of Toxocara excretory-secretory antigens (TES). The protein concentrated by the tested membrane was compared with that obtained using a Sigma commercial membrane, as were the protein fractions found by polyacrylamide gel electrophoresis. Standard positive and negative serum samples were evaluated in an ELISA immunoassay, and equivalent data were obtained in all steps, indicating that the sausagecasing membrane is efficient, besides being less expensive to process.
\end{abstract}

Uniterms: Toxocara canis/excretory-secretory antigens. Antigens/isolation. Dialysis.

O objetivo do presente estudo foi testar a eficácia de uma membrana utilizada para o preparo de embutidos, na obtenção do antígeno de excreção e secreção de Toxocara (TES). A concentração protéica foi comparada com a obtida com a membrana Sigma tanto quanto as frações protéicas separadas por eletroforese em gel de poliacrilamida. Amostras de soros padrão positivo e negativo foram avaliadas no teste imunoenzimático ELISA. Dados equivalentes foram observados em todas as etapas, sugerindo que a membrana possa ser utilizada para diálise por ser eficiente e de menor custo no preparo do antígeno.

Unitermos: Toxocara canis/antígenos de excreção e secreção. Antígenos/isolamento. Diálise.

\section{INTRODUCTION}

Toxocariasis is a zoonotic disease caused by ascarid nematodes of the genus Toxocara. Human infection occurs by accidental ingestion of embryonated eggs of $T$. canis or T. cati, intestinal parasites of dogs and cats respectively, found in soil and sand contaminated with the faeces of these animals (Beaver, 1956).

Enzyme-linked immunosorbent assay (ELISA) has proven an excellent tool in the diagnosis of toxocariasis, used in combination with clinical and laboratory data. In Brazil, laboratory diagnosis is performed only by certain health services, because of the high cost and limited availability of commercial kits (Rubinsky-Elefant et al., 2006b).

As an antigen for serology, Toxocara excretedsecreted antigens (TES) obtained from second-stage

\footnotetext{
*Correspondence: A. L. F. Guilherme. Departamento de Análises Clínicas, Universidade Estadual de Maringá. Av. Colombo, 5790 - 87020-900 - Maringá - PR, Brazil. E-mail: alfguilherme@uem.br
}

Toxocara canis larvae have proved to be the best choice because of their specificity (De Savigny, 1975). These antigens can be obtained in vitro from larvae maintained in culture medium, free of macromolecules, which produce material with antigenic activity. The TES antigen is composed of different molecules of protein that are excreted by the larva or released from its surface. Its performance and composition can be influenced by differences in the techniques used to maintain the larvae. The top five TES molecules separated by polyacrylamide gel electrophoresis have 32, 55, 70, 120, and $400 \mathrm{kDa}$ (Rubinsky-Elefant et al., 2001). The antigen production process involves a dialysis step that is required to eliminate the components of the culture medium. The dialysis membrane is obtained from laboratory supply companies, and is relatively expensive. The purpose of this study was to test the effectiveness of a low-cost commercially available sausage-casing membrane, for dialysis in the production of TES antigen. 


\section{MATERIAL AND METHODS}

\section{Production of TES antigen}

The TES antigen was produced according to De Savigny et al. (1979), as modified by Rubinsky-Elefant et al. (2006a).

Eggs of T. canis were obtained by dissecting adult female specimens obtained from the São Paulo Center for Zoonoses Control. To promote the development of infective larvae, eggs were incubated in $2 \%$ formalin for approximately 1 month, at $28{ }^{\circ} \mathrm{C}$ with daily stirring. After incubation, the eggs were repeatedly washed with saline and centrifuged for three minutes at 2,000 rpm to remove the formalin. Subsequently, $5 \%$ sodium hypochlorite was added for five minutes to lyse the chitin-protein layer, which was then washed with saline solution. To release the larvae, the material was placed in a flask containing glass beads, with Eagle medium plus gentamicin, at $37^{\circ} \mathrm{C}$, and subjected to gentle mechanical agitation. After a few minutes, this material was filtered in a modified Baermann apparatus, and the larvae were collected in sterile tubes and cultured in Eagle medium at $37^{\circ} \mathrm{C}$.

The excretion and secretion products of the larvae were collected weekly by drawing up the supernatant of the cultures. The protease inhibitor 0.2 M PMSF (phenylmethylsulfonyl fluoride) was added to the supernatant, and the mixture was stored at $-20^{\circ} \mathrm{C}$. Subsequently, the supernatant samples were concentrated 50 to 100 times in an Amicon device with a YM10 membrane (Amicon Company, Cleveland, USA) and divided into two aliquots of approximately $7.0 \mathrm{~mL}$ used to test the effectiveness of the prepared commercial sausage-casing membrane (Trip cellulose, size 34USA, Viscofan Company, Brazil) compared with the Sigma (St. Louis, CA, USA) membrane (D-9777, retention over 12,000 Da) for dialysis in distilled water.

\section{Preparation of the sausage-casing membrane (SCM) for use in dialysis}

The membrane was boiled in a solution of distilled water with 5\% neutral detergent to remove hydrophilic and lipophilic dirt. After five minutes of boiling, the membrane was rinsed several times with distilled water to eliminate the detergent.

\section{Evaluation of the sausage-casing membrane in the dialysis process}

Using $7.0 \mathrm{~mL}$ aliquots of the antigen solution, the dialysis was carried out using either a Sigma membrane (SM) or a sausage-casing membrane (SCM), in order to compare protein retention. The protein content was estimated (Lowry, 1951) after the dialyzed material had been centrifuged at 15,000 rpm for 30 minutes and filtered through a $0.22 \mu \mathrm{m}$ Millipore membrane.

\section{Evaluation of protein fractions}

The protein fractions of the dialyzed Sigma membrane (TESsm) and sausage-casing (TESscm) antigens were separated by polyacrylamide gel electrophoresis in the presence of sodium dodecyl sulfate (SDS- PAGE) (Laemmli, 1970) in a Mini-Protean II Multiscreen Apparatus (Bio-Rad) at $120 \mathrm{~V}$. The TES antigen $(15 \mu \mathrm{g} / \mathrm{lane})$ was diluted in sample buffer containing $\beta$-mercaptoethanol, boiled for 2 minutes, and applied to a $10 \%$ polyacrylamide gel. A standard molecular weight (Sigma) was used, containing the following proteins: carbonic anhydrase (29 kDa), ovalbumin (45 kDa), bovine serum albumin (66 kDa), phosphorylase B (97.4 kDa), $\beta$-galactosidase $(116 \mathrm{kDa})$, and myosin (205 kDa). After electrophoresis, the gel was silver-stained (Nielsen, 1984).

\section{Evaluating the effectiveness of the TESscm}

The effectiveness of the antigens obtained for diagnostic purposes was also tested by ELISA, using samples of two negative serum samples control, one limiar reactive serum sample (LRS), one titred positive serum sample control, and ten serum samples from patients (diluted from $1 / 80$ to $1 / 10,240$ - two-fold serially diluted). The serum samples were previously absorbed with antigens of Ascaris suum to test for anti-Toxocara spp. by the ELISA method (Rubinsky-Elefant, 2001).

\section{RESULTS AND DISCUSSION}

After dialysis, the protein concentrations obtained were $1.45 \mathrm{mg} / \mathrm{mL}$ for TESsm and $2.02 \mathrm{mg} / \mathrm{mL}$ for TESs$\mathrm{cm}$. Therefore, the amount concentrated in TESscm was $39.3 \%$ higher than that in TESsm.

The TESscm polyacrylamide electrophoresis gel showed an equivalent pattern to that of TESsm, i.e., 105$120,70,55,44$, and 31-35 kDa (Figure 1).

The ELISA serological test results, using plates sensitized either with TESscm or TESsm antigen, both produced equivalent data to the standard positive serum (Table I) and the serum sample from patients (Table II).

The comparative analysis between the membranes for dialysis in water showed that the sausage-casing membrane (SCM) was able to retain the main protein fractions that comprise the TES antigen. This result is evident when 


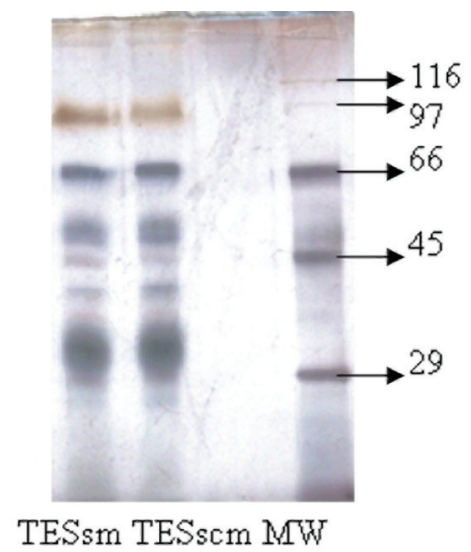

FIGURE 1 - Toxocara excretory-secretory antigens: TESsm: Sigma membrane, or TESscm: a sausage-casing membrane, in a $10 \%$ sodium dodecyl sulfate polyacrylamide gel (SDSPAGE) with silver staining; MW- standard marker for molecular weight $(\mathrm{kDa})$.

TABLE I - Absorbances of the positive serum control in the Enzyme-Linked Immunosorbent assay (ELISA) with plates coated with Toxocara excretory-secretory antigens TESsm and TESscm

\begin{tabular}{lcc}
\hline Serum Dilution & $\begin{array}{c}\text { TESsm } \\
\text { Absorbance }\end{array}$ & $\begin{array}{c}\text { TESscm } \\
\text { Absorbance }\end{array}$ \\
\hline $1 / 160$ & 0.733 & 0.886 \\
$1 / 320$ & 0.591 & 0.742 \\
$1 / 640$ & 0.444 & 0.562 \\
$1 / 1280$ & 0.291 & 0.398 \\
$1 / 2560$ & 0.176 & 0.264 \\
$1 / 5120$ & 0.094 & 0.151 \\
$1 / 10240$ & 0.044 & 0.086 \\
$1 / 20480$ & 0.027 & 0.066 \\
\hline
\end{tabular}

one observes the similarity between the absorbances of the positive serum control, and the titers of the serum obtained with plates coated with Toxocara excretory-secretory antigens TESsm and TESscm. Although serum no. 9 showed different titers in the two plates, a difference of one titer is not significant, and we can therefore conclude that the reaction was excellent.

Few public-health services in Brazil presently provide a laboratory diagnosis of toxocariasis (Figueredo et al., 2005; Paludo et al., 2007; Rubinsky-Elefant et al., 2008) However, epidemiological studies show a high prevalence of anti- $T$. canis in several regions of the country (Alderete et al., 2003; Damian et al., 2007; PrestesCarneiro et al., 2008; Colli et al., 2010). In most cases, migration of infected larvae through the tissues of humans does not result in clinical manifestations (Bass et al., 1983; Shantz, 1989). However, it can cause fever, hepatomegaly,
TABLE II - Titres of the serum from patients in the EnzymeLinked Immunosorbent Assay (ELISA) with plates coated with Toxocara excretory-secretory antigens TESsm and TESscm

\begin{tabular}{lcc}
\hline Serum number & $\begin{array}{c}\text { TESsm } \\
\text { Titers }\end{array}$ & $\begin{array}{c}\text { TESscm } \\
\text { Titers }\end{array}$ \\
\hline 1 & $1 / 160$ & $1 / 160$ \\
2 & $\geq 10240$ & $\geq 10240$ \\
3 & $1 / 80$ & $1 / 80$ \\
4 & $<80$ & $<80$ \\
5 & $1 / 1280$ & $1 / 1280$ \\
6 & $1 / 640$ & $1 / 640$ \\
7 & $<80$ & $<80$ \\
8 & $<80$ & $<80$ \\
9 & $1 / 80$ & $<80$ \\
10 & $1 / 80$ & $1 / 80$ \\
\hline
\end{tabular}

splenomegaly, respiratory symptoms, muscle pain, and damage to the eyeball (Glickman et al., 1985; Taylor et al., 1988). Complications involving asthma for example, are common in patients treated in pulmonology services in Brazil.

There are some difficulties in reaching a laboratory diagnosis of this zoonosis, such as the low sensitivity and specificity (Barros et al., 2003) and high cost (RubinskyElefant et al., 2006b) of commercial diagnostic kits. Some studies have described methodological modifications that significantly improved, quantitatively and qualitatively, the obtention of T. canis larvae (Smith, 1989; Alcantara Nevesa et al., 2008). However, none of these reduced the costs involved. The sausage-casing membrane is inexpensive (approximately 100 times cheaper than the Sigma membrane).

\section{CONCLUSION}

The sausage-casing membrane was able to replace the Sigma membrane in the dialysis process, and could also be used in the stage of concentrating the TES antigen, replacing the Amicon process. Therefore, the use of sausage-casing membrane may allow the production of TES antigens at a reduced cost, and will be valuable for laboratories with limited financial resources.

\section{REFERENCES}

ALCÂNTARA-NEVESA, N. M.; SANTOS, A. B.; MENDONÇA, L. R.; FIGUEIREDO, C. A. V.; PONTESDE-CARVALHO, L. An improved method to obtain antigen-excreting Toxocara canis larvae. Exp. Parasitol., v.119, p.349-351, 2008. 
ALDERETE, J. M. S.; JACOB, C. M. A.; PASTORINO A. C.; RUBINSKI-ELEFANT, G.; CASTRO, A. P. M.; FOMIN, A. B. F.; CHIEFFI, P. P. Prevalence of Toxocara infection in schoolchildren from the Butantã Region, São Paulo, Brazil. Mem. Inst. Oswaldo Cruz, v.98, p.593-597, 2003.

BARROS, L. P. S.; CARMO, E. L.; RUBINSKY-ELEFANT, G.; NASCIMENTO, E.; PÓVOA, M. M. Avaliação de kit comercial no diagnóstico da toxocaríase humana em estudantes do bairro do Telégrafo. Rev. Soc. Bras. Med. Trop., v.36, p.194, 2003.

BASS, J. L.; MEHTA, K. A.; GLICKMAN, L. T.; EPPS, B. M. Clinically inapparent Toxocara infection in children. $N$. Engl. J. Med., v.308, p.723-724, 1983.

BEAVER, P. C. Larva migrans. Exp. Parasitol., v.5, p.587-621, 1956.

COLLI, C. M.; RUBINSKY-ELEFANT, G.; PALUDO, M.L.; FALAVIGNA, D.L.M.; GUILHERME, E.V.; MATTIA, S.; ARAÚJO, S.M.; FERREIRA, E.C.; PREVIDELLI, I.T.S.; FALAVIGNA-GUILHERME, A.L. Serological, clinical and epidemiological evaluation of toxocariasis in urban areas of south Brazil. Rev. Inst. Med. Trop. S. Paulo, v.52, p. 69-74, 2010.

DAMIAN, M. M.; MARTINS, M.; SARDINHA, J. F.; SOUZA, L. O.; CHAVES, A.; TAVARES, A. M. Frequency of the antibody anti-Toxocara canis in a community along the Uatumã River, State of Amazonas. Rev. Soc. Bras. Med. Trop., v.40, p.661-664, 2007.

DE SAVIGNY, D.H. In vitro maintenance of Toxocara canis larvae and a simple method for the production of Toxocara ES antigens for use in serodiagnostic tests for visceral larva migrans. J. Parasitol., v.61, p.781-782, 1975.

DE SAVIGNY, D. H.; VOLLER, A.; WOODRUFF, A. W. Toxocariasis: serological diagnosis by enzyme immunoassay. J. Clin. Pathol., v.32, p.284-288, 1979.

FIGUEIREDO, S. D. P.; TADDEI, A. A. C.; MENEZES, J. J. C.; NOVO, N. F.; SILVA, E. O. M.; CRISTÓVÃO, H. L. G.; CURY, M. C. F. S. Estudo clínico-epidemiológico da toxocaríase em população infantil. J. Pediatr., v.81, p.126$132,2005$.

GLICKMAN, L. T.; GRIEVE, R. B.; LAURIA, S. S.; JONES, D. L. Serodiagnosis of ocular toxocariasis: a comparison of two antigens. J. Clin. Pathol., v.38, p.103-107, 1985.
LAEMMLI, U. K. Cleavage of structural proteins during the assembly of the head of the bacteriophage T4. Nature, v.227, p.680-685, 1970.

LOWRY, O. H.; ROSEBROUGH, N. J.; FARR, A. L.; RANDAL, R. J. Protein measurement with the folin phenol reagent. J. Biol. Chem., v.193, p.265-275, 1951.

NIELSEN, J. B. The basis for colored silver-protein complex formation in stained polyacrylamide gels. Anal. Biochem., v.141, p.311-315, 1984.

PALUDO, L. M.; FALAVIGNA, D. L. M.; ELEFANT, G. R.; GOMES, M. L.; BAGGIO, M. L. M; AMADEI, L. B.; FALAVIGNA-GUILHERME, A. L. Frequency of Toxocara infection in children attended by the health public service of Maringá, South Brazil. Rev. Inst. Med. Trop. São Paulo, v.49, p.343-348, 2007.

PRESTES-CARNEIRO, L. E.; SANTARÉM, V.; ZAGO, S. C.; MIGUEL, N. A.; ZAMBELLI, S. F.; VILLAS, R.; VAZ, A. J.; RUBINSKY-ELEFANT, G. Sero-epidemiology of toxocariasis in a rural settlement in São Paulo state, Brazil. Ann. Trop. Med. Parasitol., v.102, p.347-356, 2008.

RUBINSKY-ELEFANT, G.; JACOB, C. M. A.; KANASHIRO, E. H. Y.; PERES, B. A. Toxocaríase. In: FERREIRA, A. W.; AVILA, S.L.M., (Eds.). Diagnóstico laboratorial das principais doenças infecciosas e auto-imunes. 2.ed. Rio de Janeiro: Guanabara Koogan, 2001. p.323-332.

RUBINSKY-ELEFANT, G.; SHIMIZU, S. H.; SANCHEZ, M. C. A.; JACOB, C. M. A.; FERREIRA, A. W. A serological follow-up of toxocariasis patients after chemotherapy based on the detection of $\operatorname{IgG}, \operatorname{IgA}$ and $\operatorname{IgE}$ antibodies by enzyme-linked immunosorbent assay. J. Clin. Lab. Anal., v.20, p.164-172, 2006a.

RUBINSKY-ELEFANT, G.; SATO, M. S.; MASCARETTI, L. F. B.; FERREIRA, A. W. Avaliação de Kit comercial para o diagnóstico da toxocaríase humana. NewsLab, v.77, p.168-176, 2006 b.

RUBINSKY-ELEFANT, G.; SILVA-NUNES, M.; MALAFRONTE, R. S.; MUNIZ, P. T.; FERREIRA, M. U. Human toxocariasis in rural Brazilian Amazonia: seroprevalence, risk factors, and spatial distribution. Am. J. Trop. Med. Hyg., v.79, p.93-98, 2008.

SCHANTZ, P. M. Toxocara larva Migrans now. Am. J. Trop. Med. Hyg., v.41, p.21-34, 1989. 
SMITH, H. V. A rapid method for hatching infective eggs of Toxocara canis. Trans. R. Soc. Trop. Med. Hyg., v.83, p.250, 1989.
TAYLOR, M. R.; KEANE, C. T.; O'CONNOR, P. MULVIHILL, E.; HOLLAND, C. The expanded spectrum of toxocaral disease. Lancet, v.26, p.692-695, 1988.

Received for publication on $17^{\text {th }}$ June 2009 Accepted for publication $07^{\text {th }}$ October 2010 